\title{
Seasonal differences in oxygenated organic aerosol composition: implications for emissions sources and factor analysis
}

\author{
F. Canonaco, J. G. Slowik, U. Baltensperger, and A. S. H. Prévôt \\ Laboratory of Atmospheric Chemistry, Paul Scherrer Institute, 5232 Villigen PSI, Switzerland \\ Correspondence to: A. Prévôt (andre.prevot@psi.ch)
}

Received: 25 September 2014 - Published in Atmos. Chem. Phys. Discuss.: 13 November 2014

Revised: 23 April 2015 - Accepted: 10 May 2015 - Published: 29 June 2015

\begin{abstract}
Aerosol chemical speciation monitor (ACSM) measurements were performed in Zurich, Switzerland, for 13 months (February 2011 through February 2012). Many previous studies using this or related instruments have utilized the fraction of organic mass measured at $m / z 44\left(f_{44}\right)$, which is typically dominated by the $\mathrm{CO}_{2}^{+}$ion and related to oxygenation, as an indicator of atmospheric aging. The current study demonstrates that during summer afternoons, when photochemical processes are most vigorous as indicated by high oxidant - OX $\left(\mathrm{O}_{3}+\mathrm{NO}_{2}\right), f_{44}$ for ambient secondary organic aerosol (SOA) is not higher but is rather similar or lower than on days with low OX. On the other hand, $f_{43}$ (less oxidized fragment) tends to increase. These changes are discussed in the $f_{44} / f_{43}$ space frequently used to interpret ACSM and aerosol mass spectrometer (AMS) data. This is likely due to the formation of semi-volatile oxygenated aerosol produced from biogenic precursor gases, whose emissions increase with ambient temperature.

In addition, source apportionment analyses conducted on winter and summer data using positive matrix factorization (PMF) yield semi-volatile oxygenated organic aerosol (SVOOA) factors that retain source-related chemical information. Winter SV-OOA is highly influenced by biomass burning, whereas summer SV-OOA is to a high degree produced from biogenic precursor gases. These sources contribute to substantial differences between the winter and summer $f_{44} / f_{43}$ data, suggesting that PMF analysis of multiseason data employing only two OOA factors cannot capture the seasonal variability of OOA.
\end{abstract}

\section{Introduction}

Atmospheric aerosols are at the center of scientific and political discussions due to their highly uncertain direct and indirect climate effects (IPCC, 2007), their adverse impacts on human health (Peng et al., 2005), and their influence on our inhabited (Watson, 2002) and agricultural areas (Matson et al., 2002). Reliable identification and quantification of aerosol sources is essential for developing control strategies. The concentrations of particulate matter have generally decreased in the last 10-20 years in Europe and Switzerland but legal thresholds are still often exceeded (Barmpadimos et al., 2011, 2012). Atmospheric aerosols are classified based on their formation processes as primary and secondary aerosols, which are directly emitted into the atmosphere and formed from gas to particle conversion, respectively. Recently, the scientific focus has shifted towards submicron particulate matter $\left(\mathrm{PM}_{1}\right)$ (Hallquist et al., 2009), especially the organic fraction, which typically comprises $20-90 \%$ of the total submicron aerosol mass (Jimenez et al., 2009).

Aerodyne aerosol mass spectrometers (AMS), including the aerosol chemical speciation monitor (ACSM), have become important and widely employed instruments for the chemical characterization of submicron organic aerosol (OA) (Canagaratna et al., 2007; Ng et al., 2011b). These instruments provide online quantitative mass spectra of the non-refractory (inorganic and organic) aerosol composition with high time resolution. Frequently, the organic fraction is further analyzed (Lanz et al., 2007; Ulbrich et al., 2009; Zhang et al., 2011) using the positive matrix factorization (PMF) algorithm proposed by Paatero and Tapper (1994), which represents the organic mass spectral matrix as a set of source/process-related factor mass spectra and time series. Compilation and comparison of northern hemispheric data 
sets led to the characterization of secondary organic aerosol (SOA)-related factors as semi-volatile and low volatility oxygenated organic aerosol (SV-OOA and LV-OOA) (Jimenez et al., 2009; $\mathrm{Ng}$ et al., 2010). The SV-OOA mass spectra have a higher fraction of $m / z 43$ to organic mass $\left(f_{43}\right)$ and a lower fraction of $m / z 44$ to organic mass $\left(f_{44}\right)$ relative to $\mathrm{LV}$ OOA. SV-OOA and LV-OOA factors derived from ambient PMF analyses yield a triangle in the $f_{44} / f_{43}$ space ( $\mathrm{Ng}$ et al., 2010). SV-OOA usually represents freshly formed OOA, whereas LV-OOA may result from photochemical aging of SV-OOA, direct gas phase to LV-OOA conversion (Ehn et al., 2014), or aqueous-phase chemistry, all of which lead to a net increase of OOA $f_{44}$ with atmospheric age (Hallquist et al., 2009).

Evidence from several smog chamber and ambient studies suggests that the location in the $f_{44} / f_{43}$ space could carry information on the source of SV-OOA. The generation of SOA from smog chamber experiments indicates that for a given $f_{44}$ SOA formed from wood burning experiments (Hennigan et al., 2011; Heringa et al., 2011) yields lower $f_{43}$ than from biogenic precursors (Alfarra et al., 2012; Chhabra et al., 2011; Ng et al., 2010; Pfaffenberger et al., 2013). Recently, some ambient studies also showed that the $f_{43}$ and $f_{44}$ points lie in specific regions in the triangular space depending on the season (Crippa et al., 2014; Freney et al., 2011, 2014; Ge et al., 2012). However, the ambient studies showing the raw data points consider the total $f_{43}$ and $f_{44}$ fraction rather than the model-derived OOA. Thus, the position of these points is affected by the contribution of the primary sources, whereas in $\mathrm{Ng}$ et al. (2010) the triangular space referred to the modeled OOA factors, i.e., SV-OOA and LVOOA only.

Photochemical oxidation constitutes a major production pathway for OOA. The tropospheric ozone concentration is mainly generated from the oxidation of volatile organic compounds (VOCs) initiated by the $\mathrm{OH}$ radical and is thus a useful indicator for photochemical activity. The net oxidation of the simplest VOC, methane $\left(\mathrm{CH}_{4}\right)$ with oxygen $\left(\mathrm{O}_{2}\right)$ leading to carbon monoxide $(\mathrm{CO})$, water $\left(\mathrm{H}_{2} \mathrm{O}\right)$, hydroxyl radical $(\mathrm{OH})$, and ozone $\left(\mathrm{O}_{3}\right)$, is represented in the presence of $\mathrm{NO}_{x}$ as follows (Seinfeld and Pandis, 2006):

$\mathrm{CH}_{4}+8 \mathrm{O}_{2} \rightarrow \mathrm{CO}+\mathrm{H}_{2} \mathrm{O}+2 \mathrm{OH}+4 \mathrm{O}_{3}$.

The ozone molecules produced by these oxidation reactions participate in a rapid equilibrium between $\mathrm{NO}$ and $\mathrm{NO}_{2}$, involving the photolysis of $\mathrm{NO}_{2}$, summarized by

$\mathrm{NO}+\mathrm{O}_{3} \leftrightarrow \mathrm{NO}_{2}+\mathrm{O}_{2}$.

The sum of $\mathrm{O}_{3}$ and $\mathrm{NO}_{2}$ concentrations, defined as the oxidant - OX (Alghamdi et al., 2014; Clapp and Jenkin, 2001; Jenkin, 2014), is therefore a proxy for atmospheric aging in the troposphere.

Lagrangian studies investigating the evolution of air parcels moving downwind from a city have shown an in- crease of the LV-OOA to SV-OOA ratio (implying an increase in total OOA $f_{44}$ ) as a function of the distance from the city center (Jimenez et al., 2009). However, field campaigns and monitoring networks typically rely on stationary measurements, representing Eulerian studies instead, for which the relationship between aging (i.e., OX) and $f_{44}$ is not strictly given.

In this study, ACSM aerosol mass spectra measured in Zurich between February 2011 and February 2012 are analyzed using the PMF algorithm in the multilinear engine (ME-2) implementation (Paatero, 1999). The transformation of OOA during the aging processes in summer is related to OX and temperature. Moreover, the OOA composition is characterized in terms of $f_{44}$ and $f_{43}$, investigating the extent to which precursor sources can be inferred from these values.

\section{Materials and methods}

\subsection{Measurements}

The instruments and the methods employed for this study were described in detail by Canonaco et al. (2013), and only a brief overview is presented here. An ACSM (Aerodyne Research, Inc., Billerica, MA, USA) was deployed at the Kaserne station, an urban background station in the city center of Zurich (Switzerland), from February 2011 to February 2012. The ACSM is a compact AMS, designed for longterm measurements of non-refractory particulate matter with vacuum aerodynamic diameters between approximately 60 and $600 \mathrm{~nm}$, typically denoted as NR-PM1. The instrument is described in detail by $\mathrm{Ng}$ et al. (2011b). For a detailed description of AMS operation and analysis principles, the reader is referred to Jayne et al. (2000), Jimenez et al. (2003), Allan et al. (2003, 2004), and Canagaratna et al. (2007).

The meteorological data and trace gases were measured with conventional instruments by the Swiss National Air Pollution Monitoring Network, NABEL (Empa, 2011). The time resolution of all these instruments was $10 \mathrm{~min}$. $\mathrm{NO}_{x}$ was measured by chemiluminescence spectroscopy (Horiba APNA 360), whereas UV absorption was employed to measure the concentration of ozone (Thermo Environmental Instruments (TEI) 49C, Thermo Electron Corp., Waltham, MA). An aethalometer (AE 31, Magee Scientific Inc.) was utilized to retrieve the concentration of equivalent black carbon (EBC).

\subsection{The multilinear engine}

ME-2 (Paatero, 1999) is an engine for solving the PMF algorithm (Paatero and Tapper, 1994) where a measured matrix X is deconvolved into two matrices $\mathbf{G}$ and $\mathbf{F}$ and the remaining residual matrix $\mathbf{E}$ :

$\mathbf{X}=\mathbf{G F}+\mathbf{E}$. 
In the measured matrix $\mathbf{X}$, the columns $j$ are the $m / z$ 's and each row $i$ represents a single mass spectrum over time. Note that $p$ is defined as the number of factors of the chosen model solution, i.e., the number of columns of $\mathbf{G}$ and the number of rows of $\mathbf{F}$. Each column of the matrix $\mathbf{G}$ represents the time series of a factor, whereas each row of $\mathbf{F}$ represents the factor profile (mass spectrum).

In PMF, the entries in $\mathbf{G}$ and $\mathbf{F}$ are fit using a least squares algorithm that minimizes iteratively the quantity $Q$, defined as

$Q^{\mathrm{m}}=\sum_{i=1}^{n} \sum_{j=1}^{m}\left(\frac{\mathrm{e}_{i j}}{\sigma_{i j}}\right)^{2}$.

Here $e_{i j}$ are the elements of the residual matrix $\mathbf{E}$ and $\sigma_{i j}$ are the measurement uncertainties for the input points $x_{i j}$.

It is known that PMF solutions suffer from rotational ambiguity (Paatero et al., 2002), i.e., multiple combinations of $\mathbf{G}$ and $\mathbf{F}$ can be found that yield similar $Q$. Thus, for AMS/ACSM data the solution space needs to be explored in order to find the most environmentally reasonable and interpretable solution according to the recommendations discussed in Ulbrich et al. (2009), Canonaco et al. (2013) and Crippa et al. (2014).

In this study, rotations are explored using the $a$ value approach, which was first introduced by Lanz et al. (2008) for AMS data, employed for ACSM data in Canonaco et al. (2013) and systematically tested on 25 AMS data sets in Crippa et al. (2014). Within this method, the user directs the algorithm towards useful rotations by constraining factor profiles (as done here) and/or factor time series based on a priori information (Paatero and Hopke, 2009).

Briefly, the $a$ value determines the extent to which a given factor profile $\left(f_{j \text {, solution }}\right)$ is allowed to vary with respect to its predefined profile value $\left(f_{j}\right)$ during the model iteration:

$f_{j, \text { solution }}=f_{j} \pm a \cdot f_{j}$,

where the index $j$ denotes a measured variable (i.e., $m / z$ ) and the $a$ value is its scalar product. As an example, an $a$ value of 0.1 allows for a variability of $\pm 10 \%$.

Generally, primary aerosol components are assumed to be unaffected by meteorological and chemical aging processes, since they represent fresh emissions. This assumption is empirically supported by the similarities in primary organic aerosol (POA) profiles retrieved in PMF analyses at many sites, e.g., in $\mathrm{Ng}$ et al. (2011a). This allows the model to be constrained using POA factor profiles from other PMF studies and allowing data set-specific optimizations with the ME-2 solver using the $a$ value technique. In contrast to POA, OOA profiles (i.e., SOA composition) depend on many parameters, e.g., precursor gases, aging processes, and atmospheric conditions. To appropriately constrain an OOA profile, the effect of these considerations on the spectral profiles must be known. Therefore, OOA factors are not constrained but rather allowed to be modeled by PMF.
For this study we conducted the source apportionment employing the ME-2 solver and constraining the primary aerosol components, i.e., traffic (HOA), cooking (COA), and biomass burning (BBOA) using the $a$ value approach and allowed for two additional free factors representing the secondary components. HOA and COA anchor profiles were taken from Crippa et al. (2013), where these primary sources were successfully resolved in an unconstrained PMF run. The BBOA anchor is the averaged BBOA mass spectrum reported in $\mathrm{Ng}$ et al. (2011a). The employed $a$ values are 0.1 for HOA and COA and 0.3 for BBOA. This was based on different sensitivity tests performed on the winter and summer data set separately, similar to those presented in Canonaco et al. (2013). The higher $a$ value for BBOA accounts for the fact that the biomass burning sources are more variable, as they depend strongly on the burning material and burning conditions (Hennigan et al., 2011; Heringa et al., 2012; Weimer et al., 2008).

\subsection{Estimating OOA $f_{43}$ and $f_{44}$}

The approach used in this study for estimating $f_{43}$ and $f_{44}$ for OOA involved the subtraction of the contributions from the primary sources arising at $m / z 43$ and $m / z 44$. This is slightly different from the method of $\mathrm{Ng}$ et al. (2010), where only the modeled $f_{43}$ and $f_{44}$ for SV-OOA and LV-OOA were considered. The two methods produce slightly different results because specific sources/processes are not perfectly represented by individual factors, as evidenced by the residual matrix E. In the current method, the variability not captured by the model (i.e., residuals), propagates into the calculated $f_{43}$ and $f_{44}$. This means that the total OOA variability is more fully captured by the current method, but at the cost of unintentionally including variability due to imperfectly modeled POA.

\section{Results and discussion}

\subsection{Source apportionment in winter and summer 2011}

Source apportionment was conducted separately for winter (February and March) and summer (June to August) 2011. These two seasons represent extreme cases, whereas spring and fall may be conceptualized as intermediate cases. A complete source apportionment analysis of the ACSM data of 2011/2012 is in preparation (Canonaco et al., 2015). The summer/winter 2011 results are summarized in the supplementary material. Note that the solutions are environmentally reasonable: the traffic factor correlates with $\mathrm{NO}_{x}$ and EBC, the cooking factor peaks during mealtimes (noon and evening), BBOA is higher at night and lower during the day accounting for nocturnal heating in winter and barbecuing and possible local fire events in summer, and the daily cycle of SV-OOA is anticorrelated with temperature for the winter and summer data (Figs. S3 and S6 in the Supplement). The 
a)

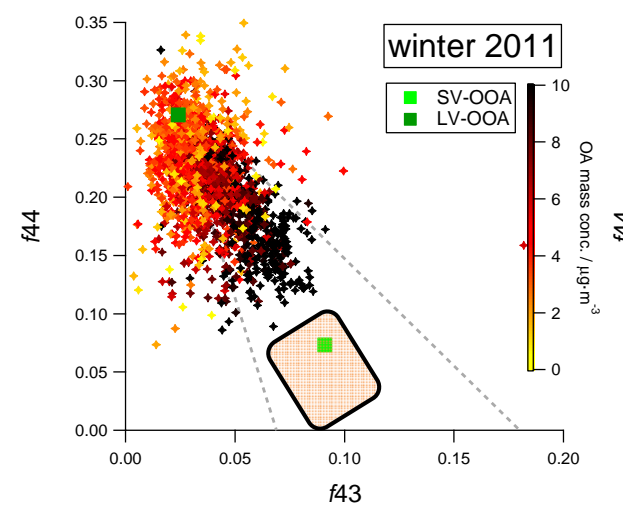

b)

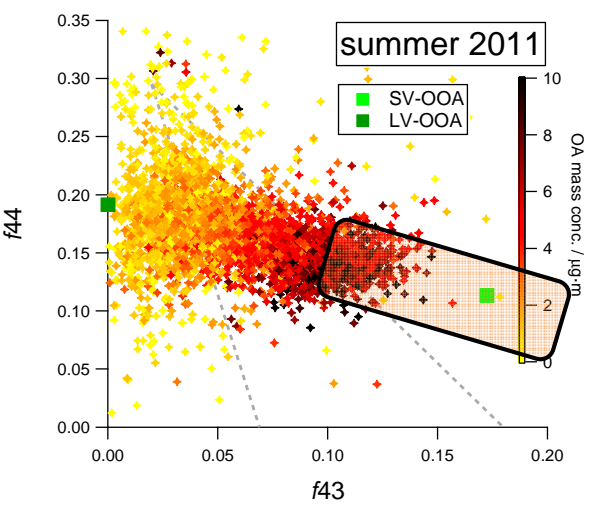

Figure 1. SOA $f_{44}$ and $f_{43}$ for winter 2011 (a) and summer 2011 (b). The data are color-coded based on the total OA mass concentration. The green points are the $f_{44}$ and $f_{43}$ ratios of SV-OOA (light green) and LV-OOA (dark green). Orange rectangles represent the composition of SOA from smog chamber experiments using biomass burning (Heringa et al., 2011) (a) and $\alpha$-pinene (Pfaffenberger et al., 2013) (b) precursors.

daily cycle of LV-OOA is rather flat (winter) or shows an increase during the afternoon (summer), representing either the conversion of SV-OOA to LV-OOA or direct LV-OOA formation from the gas phase and thus compensating the effect of boundary layer dilution and/or advecting air masses containing background LV-OOA.

Figures S3 and S6 reveal an increase in concentrations for all factors except LV-OOA during the late evening and at night in winter and summer. This is mostly governed by a smaller boundary layer in the evening compared to midday which tends to concentrate all emissions.

The OOA $f_{44} / f_{43}$ data together with the ratios of the SVOOA and LV-OOA in the $f_{44} / f_{43}$ space are summarized for both seasons in Fig. 1. This figure highlights the fact that the majority of the OOA points, especially those with high masses (data with weak signal to noise are not expected to be explained by the model), are well captured by the seasonal PMF run, since they are equally scattered (unimodal residual) around the connection line between SV-OOA and LV-OOA and hardly extend beyond these endpoints. Hence, no major systematic over- or underestimations occur. Visual inspection of Fig. 1 indicates that the SOA points do not form a cloud, but rather suggest a line. This indicates that a single OOA factor cannot adequately represent SOA spectral variability in both seasons and at least two OOA factors with consistent characteristics of SV-OOA and LV-OOA are required. Note that the different location (and apparent slope) in the $f_{44} / f_{43}$ space of the winter and summer data indicates that a combined winter/summer PMF would fail to capture the seasonal variability in OOA. The winter SV-OOA lies more on the left side of the triangular space, whereas the summer $\mathrm{SV}-\mathrm{OOA}$ is on the right side of the triangular space. These locations are comparable with the location of SOA from smog chamber studies conducted with biomass burning (Heringa et al., 2011) and $\alpha$-pinene (Pfaffenberger et al., 2013). The data from these two studies are represented with orange rectangles in Fig. 1a and b.

\subsection{Variations in the $f_{44} / f_{43}$ space for winter 2011}

The variation of the winter 2011 OOA points in the $f_{44} / f_{43}$ space shown in Fig. 1a is due to the linear combination between the winter LV-OOA and the biomass burning-related SV-OOA. Adopting the nomenclature convention proposed in Murphy et al. (2014) the winter SV-OOA, called SVbbSOA (biomass burning SV-OOA), would be due to aging of biomass burning-related VOCs emitted primarily by domestic heating, which peaks at night. Figure S1 supports the interpretation of the winter SV-OOA as originating mainly from biomass burning emissions, due to the presence of $m / z 60$, the biomass burning tracer (Alfarra et al., 2007) that has been shown to be substantial in SV-OOA (Heringa et al., 2011). SV-OOA arising from traffic emissions is likely to be a minor contribution, as the total estimated contribution of the traffic source (combined POA and SOA) for Zurich winter 2011/2012 is on average less than $20 \%$ to the total OA (Zotter et al., 2014). In comparison, the PMF result in this study ascribed on average $12 \%$ of OA to primary traffic contributions, $25 \%$ to SV-OOA, and $40 \%$ to LV-OOA. Even if the remaining traffic SOA contribution were completely assumed to be SV-OOA, this would still be a minor part of the total SV-OOA.

SV-OOA has a lower $f_{44}$ compared to the SV-OOA in summer (see Sect. 3.3). Nonetheless, the $f_{44}$ of LV-OOA in winter is higher than that of LV-OOA in summer despite reaching similarly low $f_{43}$ values. A possible explanation could be aqueous-phase production of LV-OOA (either directly or via processing of SV-OOA) in clouds or humidified 
a)

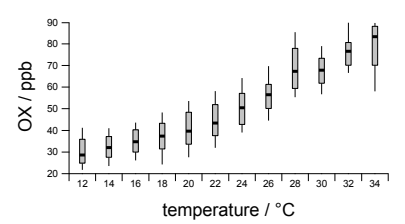

c)

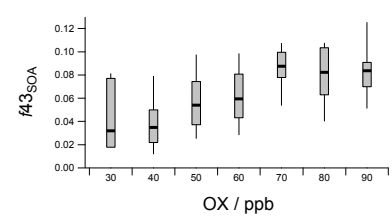

Figure 2. Box plots for the summer data: (a) $\mathrm{OX}\left(\mathrm{O}_{3}+\mathrm{NO}_{2}\right)$ as a function of the afternoon temperature $\left(T_{\max } \pm 2 \mathrm{~h}\right)$, (b) SOA $f_{44}$ as a function of the afternoon OX and (c) SOA $f_{43}$ as a function of the afternoon OX. The horizontal lines denote the median, the boxes span the quartiles and the whiskers represent the 10th and 90th percentiles.

aerosols, which are believed to increase oxygenation above that predicted by gas-phase reaction/condensation mechanisms (Ervens et al., 2011; George et al., 2008; Slowik et al., 2012). However, due to the lack of experimental data and ambient tracers for such mechanisms, this hypothesis remains speculative.

\subsection{Variations in the $f_{44} / f_{43}$ space for the summer 2011}

\subsubsection{General trends}

The variation of the summer 2011 OOA data in the $f_{44} / f_{43}$ space shown in Fig. 1 can be described as a linear combination of the summer LV-OOA and SV-OOA (see Sect. 3.2). The relation between temperature and OX for the measured data is shown in Fig. 2a. Note that OX is plotted as a function of the maximal daily temperature $\pm 2 \mathrm{~h}$ to capture the period of highest photochemical activity. This strong relation implies that the photochemical oxidation is highest for days with high temperature. However, the relation between $f_{44}$ and $\mathrm{OX}$ is rather flat if not slightly inversely proportional as highlighted in Fig. 2b. On the contrary, $f_{43}$ shows a proportional dependence on the afternoon OX values (Fig. 2c). This is consistent with increased production of SV-OOA relative to LV-OOA, i.e., with increased VOC precursors in the atmosphere. Given the season and elevated temperatures, biogenic emissions are a likely source (Guenther, 1997). Figure 3a illustrates the clustered afternoon data on top of the summer OOA data in the $f_{44} / f_{43}$ space. Only the values in the interval of $4 \mathrm{~h}$ around the maximal daily temperature $\left(T_{\max }\right)$ were considered for the clustering. This figure elucidates the fact that the main horizontal movement of the $f_{44} / f_{43}$ OOA data is driven mainly by temperature and thus by biogenic emis- sions. Therefore, the modeled SV-OOA is predominantly of biogenic nature and has been referred to as SV-bSOA (biogenic SOA) by Murphy et al. (2014).

\subsubsection{Day and night variations}

Figure $3 b$ shows the OOA data together with two grouped families. The red points are the same as in Fig. 3a, i.e., the afternoon values only. The blue points are the clustered points between midnight to 5:00 LT of the following morning. Only early morning points are considered to avoid dilution effects from a rising boundary layer after sunrise. The comparison of the two grouped families (afternoon and subsequent early morning) suggests that semi-volatile organics generated during the day condense to the aerosol phase at night, increasing $f_{43}$ and decreasing $f_{44}$. This effect was already described Lanz et al. (2007) showing that the condensation of fresh oxygenated organic compounds (SV-OOA) was enhanced during the night and the early morning following hot summer days during a 3-week campaign with the AMS in Zurich. The fact that the ACSM data from the entire summer season in Zurich in 2011 show the same temperature-driven partitioning for SV-OOA reinforces the interpretation of the semi-volatile character of OOA2 from Lanz et al. (2007). As discussed in the previous section, the summer SV-OOA is likely governed by biogenic SV-OOA (SV-bSOA). Moreover, oxidation processes enhancing the LV-OOA fraction during the afternoon, as highlighted by the diurnal cycle in Fig. S6, will increase the diurnal $f_{44} / f_{43}$ ratio leading to a stronger separation of the their day versus night points. Only a single pair of points in Fig. 3b, at the lowest temperature (which has high statistical uncertainty due to the small number of measurements contained) violates this trend.

\subsubsection{SV-OOA vs. LV-OOA}

Figure $4 \mathrm{a}$ and $\mathrm{b}$ show summer SV-OOA and LV-OOA against the maximum afternoon temperature as calculated above (red bars) and the data between midnight and 5:00 LT of the following morning (blue bars). The SV-OOA concentration tends to increase as a function of temperature, both during the afternoon and early morning. LV-OOA shows a similar but less pronounced behavior. In Fig. 4c, the ratio (SVOOA / total OOA) is plotted against the total OOA mass concentration. For low OOA concentrations, the fraction of SV-OOA increases with increasing total OOA. However, the fraction levels off for total OOA mass concentrations above $5 \mu \mathrm{g} \mathrm{m}^{-3}$. One possible explanation could involve the departure of the exponential dependency of the biogenic VOC's emission rate from the temperature, which occurs at temperatures between 30 and $35^{\circ} \mathrm{C}$ (Smiatek and Steinbrecher, 2006).

Besides the positive trend of SV-OOA with respect to the summer afternoon temperature, the SV-OOA fraction increases as a function of total OA mass, highlighted in Figs. 4c 
a)

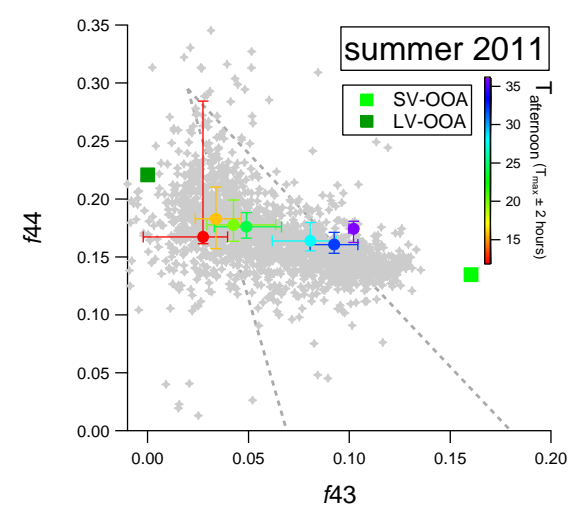

b)

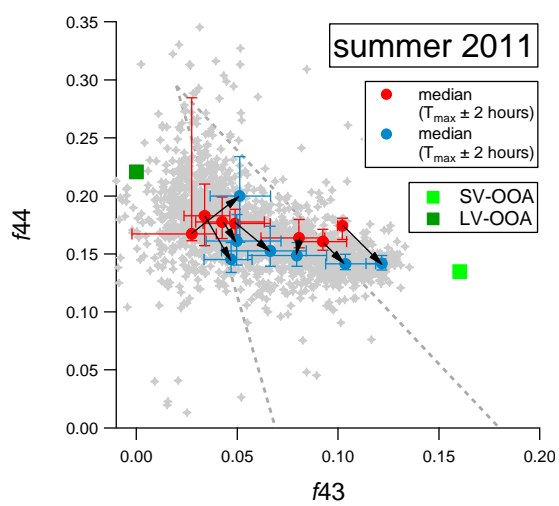

Figure 3. SOA $f_{44}$ vs. $f_{43}$ for all data points in summer 2011 (gray dots) and LV-OOA/SV-OOA factors (green squares). (a) Color-coded circles denote averages at the daily maximum temperature $\left(T_{\max }\right) \pm 2 \mathrm{~h}$. (b) Red circles denote daily $T_{\max } \pm 2 \mathrm{~h}$, while blue circles denote the average over the following midnight to 5:00 LT period. Black arrows connect corresponding day and night averages.

a)

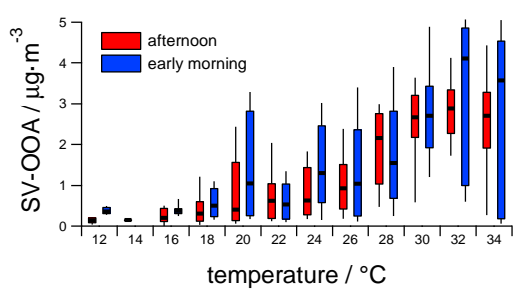

b)

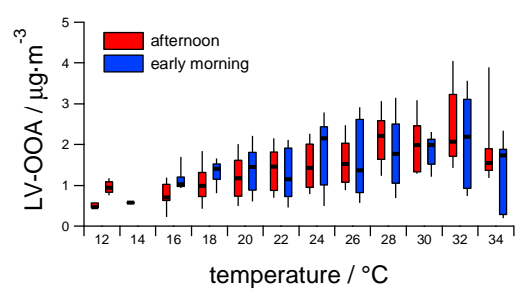

c)

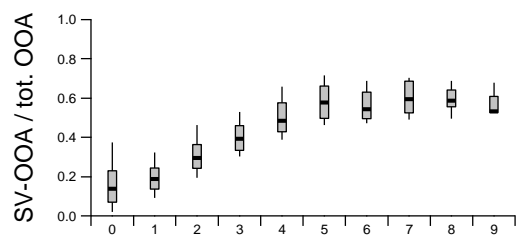

tot. OOA / $\mu \mathrm{g} \cdot \mathrm{m}^{-3}$

Figure 4. Box plots describing OOA composition, where horizontal lines indicate median values, boxes denote quartiles, and whiskers represent 10th and 90th percentiles. Quantities plotted are for the summer data: SV-OOA vs. temperature (a), LV-OOA vs. temperature (b), and SV-OOA fraction vs. total OOA mass (c). The afternoon and early morning points are estimated as $T_{\max } \pm 2 \mathrm{~h}$ and midnight to 5:00 LT, respectively.

and S7. Recently, the smog chamber study reported in Pfaffenberger et al. (2013) on aged biogenic VOC showed that the partitioning of biogenic semi-volatile organic compounds (SV-OOA) to the aerosol phase is enhanced for increased aerosol mass concentrations, resulting in a decrease of $f_{44}$ and an increase in $f_{43}$. Figure S7 shows $f_{44}$ and $f_{43}$ plotted as a function of total OA mass for the summer data together with the experimental data (L. Pfaffenberger, personal communication, 2013). Our results in the higher mass range (above $5 \mu \mathrm{g} \mathrm{m}^{-3}$ ) suggest a similar behavior for $f_{43}$, though less pronounced for $f_{44}$. One reasonable explanation could involve a slightly higher total $f_{44}$ value for the ambient data at low concentrations, due to higher photochemical aging. In addition, other reaction pathways, e.g., nitrate oxidation, or aqueous-phase reactions might also affect the ambient composition and finally, the presence of other ambient VOCs than those tested in the above-mentioned smog chamber study, would also lead to a different slope of the ambient data.

\subsubsection{SOA formation in summer}

The main ambient emission and photochemical oxidation processes are summarized in Fig. 5. The four sources relevant for this study are represented at the bottom, i.e., biogenic, 


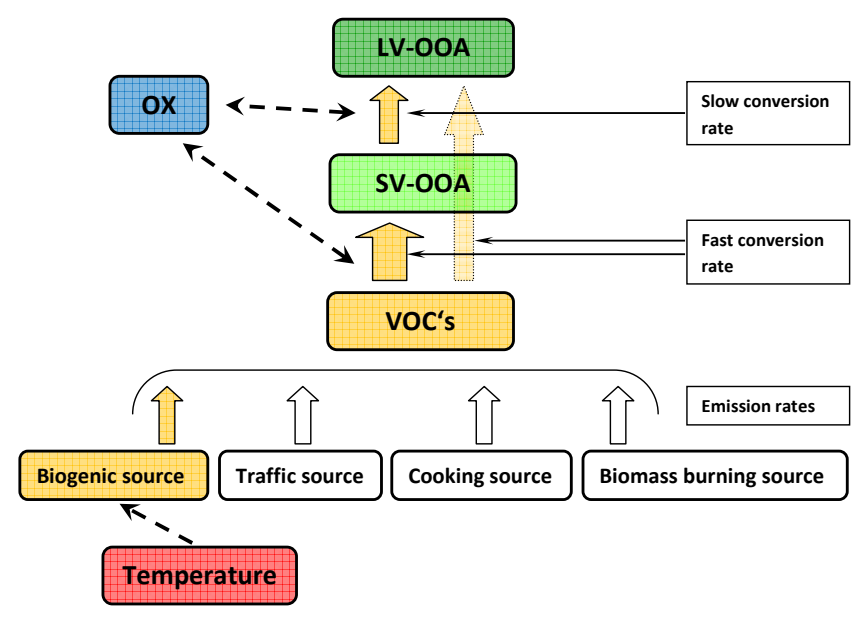

Figure 5. The simplified scheme represents the emissions and aging processes occurring in ambient during the summer afternoons. The big arrows stand for the emission/conversion rates and the dashed arrows show qualitative dependencies, with the arrow pointing towards the dependent quantity. Higher temperatures in summer primarily enhance the biogenic path (highlighted in orange).

traffic, cooking, and biomass burning. These sources emit VOCs which are transformed to SV-OOA and further to LVOOA or directly to LV-OOA (orange arrows in the figure). The concentration of $\mathrm{OX}$ in the atmosphere is related to the net aging processes and is therefore linked to the conversion from VOC to SV-OOA and/or LV-OOA and from SV-OOA to LV-OOA. The strong relation between OX and temperature highlighted in Fig. 2a suggests that photochemistry is more active during the summer afternoon. However, Fig. 2b indicates that the SOA $f_{44}$ is rather flat with increasing OX in favor of the total OOA $f_{43}$ (SV-OOA), as also shown in Fig. 2c. Substantial amounts of continuous VOC emissions in summer enhance the formation of SV-OOA in comparison to the conversion of VOC's and/or SV-OOA leading to LV-OOA. The latter is typically occurring on a timescale of hours (Jimenez et al., 2009). Higher temperatures will enhance the biogenic emissions relative to the other emission rates. As a consequence the biogenic path will dominate and the resulting SV-OOA will most likely be predominantly of biogenic nature, i.e., SV-OOA, represented as the orange path in Fig. 5.

\section{Conclusions}

This study shows that the SV-OOA modeled for ambient data by the means of the multilinear engine (ME-2) in winter and in summer retains some chemical information related to its precursor source(s). For a given $f_{44}$, biomass burning-related SV-OOA exhibits lower $f_{43}$ relative to biogenic SV-OOA, locating these two SOA factors on the left- and right-hand sides of the triangular space identified by $\mathrm{Ng}$ et al. (2010).
Periods of high photochemical activity in summer do not increase the SOA $f_{44} / f_{43}$ ratio because temperature-driven biogenic emissions and subsequent SV-OOA formation dominate over the conversion rate of SV-OOA to LV-OOA or direct formation of LV-OOA. The $f_{44} / f_{43}$ ratio is consistently lower at night than during the previous day due to the condensation of semi-volatile compounds produced during the day, predominantly from reaction of biogenic VOCs.

In summer, the OOA composition depends strongly on temperature and mass concentration for values below $5 \mu \mathrm{g} \mathrm{m}^{-3}$. This highlights the importance of biogenic VOC emissions and of the biogenic SOA production.

In addition, there were substantial differences between the winter and summer $f_{44} / f_{43}$ data indicating that a PMF result over the entire data, employing two OOA factors only, would fail to fully represent the seasonal variability of OOA.

\section{The Supplement related to this article is available online at doi:10.5194/acp-15-6993-2015-supplement.}

Acknowledgements. The ACSM measurements were supported by the Swiss Federal Office for the Environment (FOEN). The authors would like to thank L. Pfaffenberger and M. Heringa for compiling and providing their smog chamber results in the $f_{44} / f_{43}$ space, relevant for this publication. Thanks are also due to the Environmental group of the Swiss Federal Laboratories for Materials and Testing (Empa) for their support and to $\mathrm{M}$. Canonaco and S. Canonaco-Franceschini for a critical reading of this manuscript. J. Slowik acknowledges support from the Swiss National Science Foundation (SNF) in the form of Ambizione and Starting grants (PZ00P2_131673 and BSSGI0_155846).

Edited by: R. Sullivan

\section{References}

Alfarra, M. R., Prévôt, A. S. H., Szidat, S., Sandradewi, J., Weimer, S., Lanz, V. A., Schreiber, D., Mohr, M., and Baltensperger, U.: Identification of the mass spectral signature of organic aerosols from wood burning emissions, Environ. Sci. Technol., 41, 57705777, 2007.

Alfarra, M. R., Hamilton, J. F., Wyche, K. P., Good, N., Ward, M. W., Carr, T., Barley, M. H., Monks, P. S., Jenkin, M. E., Lewis, A. C., and McFiggans, G. B.: The effect of photochemical ageing and initial precursor concentration on the composition and hygroscopic properties of $\beta$-caryophyllene secondary organic aerosol, Atmos. Chem. Phys., 12, 6417-6436, doi:10.5194/acp12-6417-2012, 2012.

Alghamdi, M. A., Khoder, M., Harrison, R. M., Hyvarinen, A. P., Hussein, T., Al-Jeelani, H., Abdelmaksoud, A. S., Goknil, M H., Shabbaj, I. I., Almehmadi, F. M., Lihavainen, H., Kulmala, M., and Hameri, K.: Temporal variations of O-3 and NOx in the urban background atmosphere of the coastal city Jeddah, Saudi Arabia, Atmos. Environ., 94, 205-214, 2014. 
Allan, J. D., Jimenez, J. L., Williams, P. I., Alfarra, M. R., Bower, K. N., Jayne, J. T., Coe, H., and Worsnop, D. R.: Quantitative sampling using an Aerodyne aerosol mass spectrometer: 1. Techniques of data interpretation and error analysis, J. Geophys. Res.Atmos., 108, 4090, doi:10.1029/2002JD002358, 2003.

Allan, J. D., Delia, A. E., Coe, H., Bower, K. N., Alfarra, M. R., Jimenez, J. L., Middlebrook, A. M., Drewnick, F., Onasch, T. B., Canagaratna, M. R., Jayne, J. T., and Worsnop, D. R.: A generalised method for the extraction of chemically resolved mass spectra from Aerodyne aerosol mass spectrometer data, J. Aerosol Sci., 35, 909-922, 2004.

Barmpadimos, I., Hueglin, C., Keller, J., Henne, S., and Prévôt, A. S. H.: Influence of meteorology on $\mathrm{PM}_{10}$ trends and variability in Switzerland from 1991 to 2008, Atmos. Chem. Phys., 11, 18131835, doi:10.5194/acp-11-1813-2011, 2011.

Barmpadimos, I., Keller, J., Oderbolz, D., Hueglin, C., and Prévôt, A. S. H.: One decade of parallel fine $\left(\mathrm{PM}_{2.5}\right)$ and coarse $\left(\mathrm{PM}_{10}-\mathrm{PM}_{2.5}\right)$ particulate matter measurements in Europe: trends and variability, Atmos. Chem. Phys., 12, 3189-3203, doi:10.5194/acp-12-3189-2012, 2012.

Canagaratna, M. R., Jayne, J. T., Jimenez, J. L., Allan, J. D., Alfarra, M. R., Zhang, Q., Onasch, T. B., Drewnick, F., Coe, H., Middlebrook, A., Delia, A., Williams, L. R., Trimborn, A. M., Northway, M. J., DeCarlo, P. F., Kolb, C. E., Davidovits, P., and Worsnop, D. R.: Chemical and microphysical characterization of ambient aerosols with the Aerodyne aerosol mass spectrometer, Mass Spectrom. Rev., 26, 185-222, 2007.

Canonaco, F., Crippa, M., Slowik, J. G., Baltensperger, U., and Prévôt, A. S. H.: SoFi, an IGOR-based interface for the efficient use of the generalized multilinear engine (ME-2) for the source apportionment: ME-2 application to aerosol mass spectrometer data, Atmos. Meas. Tech., 6, 3649-3661, doi:10.5194/amt6-3649-2013, 2013.

Canonaco, F., Dällenbach, K., ElHaddad, I., Crippa, M., Bozzetti, C., Huang, R.-J., Slowik, J., Baltensperger, U., Hüglin, C., Herich, H., and Prévôt, A. S. H.: A novel strategy for the source apportionment of long-term ACSM data based on ME-2 with SoFi: Automatic Rolling SoFi (AuRo-SoFi), in preparation, 2015.

Chhabra, P. S., Ng, N. L., Canagaratna, M. R., Corrigan, A. L., Russell, L. M., Worsnop, D. R., Flagan, R. C., and Seinfeld, J. H.: Elemental composition and oxidation of chamber organic aerosol, Atmos. Chem. Phys., 11, 8827-8845, doi:10.5194/acp-11-88272011, 2011.

Clapp, L. J. and Jenkin, M. E.: Analysis of the relationship between ambient levels $\mathrm{Of}_{3}, \mathrm{NO}_{2}$ and $\mathrm{NO}$ as a function of $\mathrm{NO}_{x}$ in the UK, Atmos. Environ., 35, 6391-6405, 2001.

Crippa, M., DeCarlo, P. F., Slowik, J. G., Mohr, C., Heringa, M. F., Chirico, R., Poulain, L., Freutel, F., Sciare, J., Cozic, J., Di Marco, C. F., Elsasser, M., Nicolas, J. B., Marchand, N., Abidi, E., Wiedensohler, A., Drewnick, F., Schneider, J., Borrmann, S., Nemitz, E., Zimmermann, R., Jaffrezo, J.-L., Prévôt, A. S. H., and Baltensperger, U.: Wintertime aerosol chemical composition and source apportionment of the organic fraction in the metropolitan area of Paris, Atmos. Chem. Phys., 13, 961-981, doi:10.5194/acp-13-961-2013, 2013.

Crippa, M., Canonaco, F., Lanz, V. A., Äijälä, M., Allan, J. D., Carbone, S., Capes, G., Ceburnis, D., Dall'Osto, M., Day, D. A., DeCarlo, P. F., Ehn, M., Eriksson, A., Freney, E., Hildebrandt Ruiz,
L., Hillamo, R., Jimenez, J. L., Junninen, H., Kiendler-Scharr, A., Kortelainen, A.-M., Kulmala, M., Laaksonen, A., Mensah, A. A., Mohr, C., Nemitz, E., O’Dowd, C., Ovadnevaite, J., Pandis, S. N., Petäjä, T., Poulain, L., Saarikoski, S., Sellegri, K., Swietlicki, E., Tiitta, P., Worsnop, D. R., Baltensperger, U., and Prévôt, A. S. H.: Organic aerosol components derived from 25 AMS data sets across Europe using a consistent ME-2 based source apportionment approach, Atmos. Chem. Phys., 14, 61596176, doi:10.5194/acp-14-6159-2014, 2014.

Ehn, M., Thornton, J. A., Kleist, E., Sipila, M., Junninen, H., Pullinen, I., Springer, M., Rubach, F., Tillmann, R., Lee, B., LopezHilfiker, F., Andres, S., Acir, I.-H., Rissanen, M., Jokinen, T., Schobesberger, S., Kangasluoma, J., Kontkanen, J., Nieminen, T., Kurten, T., Nielsen, L. B., Jorgensen, S., Kjaergaard, H. G., Canagaratna, M., Dal Maso, M., Berndt, T., Petaja, T., Wahner, A., Kerminen, V.-M., Kulmala, M., Worsnop, D. R., Wildt, J., and Mentel, T. F.: A large source of low-volatility secondary organic aerosol, Nature, 506, p. 476, 2014.

Empa: Technischer Bericht zum Nationalen Beobachtungsnetz für Luftfremdstoffe, (NABEL), available at: http://www.empa.ch (last access: December 2014), 2011.

Ervens, B., Turpin, B. J., and Weber, R. J.: Secondary organic aerosol formation in cloud droplets and aqueous particles (aqSOA): a review of laboratory, field and model studies, Atmos. Chem. Phys., 11, 11069-11102, doi:10.5194/acp-1111069-2011, 2011.

Freney, E. J., Sellegri, K., Canonaco, F., Boulon, J., Hervo, M., Weigel, R., Pichon, J. M., Colomb, A., Prévôt, A. S. H., and Laj, P.: Seasonal variations in aerosol particle composition at the puy-de-Dôme research station in France, Atmos. Chem. Phys., 11, 13047-13059, doi:10.5194/acp-11-13047-2011, 2011.

Freney, E. J., Sellegri, K., Canonaco, F., Colomb, A., Borbon, A., Michoud, V., Doussin, J.-F., Crumeyrolle, S., Amarouche, N., Pichon, J.-M., Bourianne, T., Gomes, L., Prevot, A. S. H., Beekmann, M., and Schwarzenböeck, A.: Characterizing the impact of urban emissions on regional aerosol particles: airborne measurements during the MEGAPOLI experiment, Atmos. Chem. Phys., 14, 1397-1412, doi:10.5194/acp-14-1397-2014, 2014.

Ge, X. L., Setyan, A., Sun, Y. L., and Zhang, Q.: Primary and secondary organic aerosols in Fresno, California during wintertime: Results from high resolution aerosol mass spectrometry, J. Geophys. Res.-Atmos., 117, D19301, doi:10.1029/2012JD018026, 2012.

George, I. J., Slowik, J., and Abbatt, J. P. D.: Chemical aging of ambient organic aerosol from heterogeneous reaction with hydroxyl radicals, Geophys. Res. Lett., 35, L13811, doi:10.1029/2008GL033884, 2008.

Guenther, A.: Seasonal and spatial variations in natural volatile organic compound emissions, Ecol. Appl., 7, 34-45, 1997.

Hallquist, M., Wenger, J. C., Baltensperger, U., Rudich, Y., Simpson, D., Claeys, M., Dommen, J., Donahue, N. M., George, C., Goldstein, A. H., Hamilton, J. F., Herrmann, H., Hoffmann, T., Iinuma, Y., Jang, M., Jenkin, M. E., Jimenez, J. L., Kiendler-Scharr, A., Maenhaut, W., McFiggans, G., Mentel, Th. F., Monod, A., Prévôt, A. S. H., Seinfeld, J. H., Surratt, J. D., Szmigielski, R., and Wildt, J.: The formation, properties and impact of secondary organic aerosol: current and emerging issues, Atmos. Chem. Phys., 9, 5155-5236, doi:10.5194/acp-9-51552009, 2009. 
Hennigan, C. J., Miracolo, M. A., Engelhart, G. J., May, A. A., Presto, A. A., Lee, T., Sullivan, A. P., McMeeking, G. R., Coe, H., Wold, C. E., Hao, W.-M., Gilman, J. B., Kuster, W. C., de Gouw, J., Schichtel, B. A., Collett Jr., J. L., Kreidenweis, S. M., and Robinson, A. L.: Chemical and physical transformations of organic aerosol from the photo-oxidation of open biomass burning emissions in an environmental chamber, Atmos. Chem. Phys., 11, 7669-7686, doi:10.5194/acp-11-7669-2011, 2011.

Heringa, M. F., DeCarlo, P. F., Chirico, R., Tritscher, T., Dommen, J., Weingartner, E., Richter, R., Wehrle, G., Prévôt, A. S. H., and Baltensperger, U.: Investigations of primary and secondary particulate matter of different wood combustion appliances with a high-resolution time-of-flight aerosol mass spectrometer, Atmos. Chem. Phys., 11, 5945-5957, doi:10.5194/acp-11-59452011, 2011.

Heringa, M. F., DeCarlo, P. F., Chirico, R., Lauber, A., Doberer, A., Good, J., Nussbaumer, T., Keller, A., Burtscher, H., Richard, A., Miljevic, B., Prévôt, A. S. H., and Baltensperger, U.: Timeresolved characterization of primary emissions from residential wood combustion appliances, Environ. Sci. Technol., 46, 1141811425, 2012.

IPCC: IPCC Fourth Assessment Report: The Physical Science Basis, Working Group I, Final Report, Geneva, Switzerland., 2007.

Jayne, J. T., Leard, D. C., Zhang, X. F., Davidovits, P., Smith, K. A., Kolb, C. E., and Worsnop, D. R.: Development of an aerosol mass spectrometer for size and composition analysis of submicron particles, Aerosol Sci. Tech., 33, 49-70, 2000.

Jenkin, M. E.: Investigation of an oxidant-based methodology for AOT40 exposure assessment in the UK, Atmos. Environ., 94, 332-340, 2014

Jimenez, J. L., Jayne, J. T., Shi, Q., Kolb, C. E., Worsnop, D. R., Yourshaw, I., Seinfeld, J. H., Flagan, R. C., Zhang, X. F., Smith, K. A., Morris, J. W., and Davidovits, P.: Ambient aerosol sampling using the Aerodyne aerosol mass spectrometer, Geophys. Res. Atmos., 108, 8425, doi:doi:10.1029/2001JD001213, 2003.

Jimenez, J. L., Canagaratna, M. R., Donahue, N. M., Prévôt, A. S. H., Zhang, Q., Kroll, J. H., DeCarlo, P. F., Allan, J. D., Coe, H., Ng, N. L., Aiken, A. C., Docherty, K. S., Ulbrich, I. M., Grieshop, A. P., Robinson, A. L., Duplissy, J., Smith, J. D., Wilson, K. R., Lanz, V. A., Hueglin, C., Sun, Y. L., Tian, J., Laaksonen, A., Raatikainen, T., Rautiainen, J., Vaattovaara, P., Ehn, M., Kulmala, M., Tomlinson, J. M., Collins, D. R., Cubison, M. J., Dunlea, E. J., Huffman, J. A., Onasch, T. B., Alfarra, M. R., Williams, P. I., Bower, K., Kondo, Y., Schneider, J., Drewnick, F., Borrmann, S., Weimer, S., Demerjian, K., Salcedo, D., Cottrell, L., Griffin, R., Takami, A., Miyoshi, T., Hatakeyama, S., Shimono, A., Sun, J. Y., Zhang, Y. M., Dzepina, K., Kimmel, J. R., Sueper, D., Jayne, J. T., Herndon, S. C., Trimborn, A. M., Williams, L. R., Wood, E. C., Middlebrook, A. M., Kolb, C. E., Baltensperger, U., and Worsnop, D. R.: Evolution of organic aerosols in the atmosphere, Science, 326, 1525-1529, 2009.

Lanz, V. A., Alfarra, M. R., Baltensperger, U., Buchmann, B., Hueglin, C., and Prévôt, A. S. H.: Source apportionment of submicron organic aerosols at an urban site by factor analytical modelling of aerosol mass spectra, Atmos. Chem. Phys., 7, 15031522, doi:10.5194/acp-7-1503-2007, 2007.

Lanz, V. A., Alfarra, M. R., Baltensperger, U., Buchmann, B., Hueglin, C., Szidat, S., Wehrli, M. N., Wacker, L., Weimer, S., Caseiro, A., Puxbaum, H., and Prévôt, A. S. H.: Source attribu- tion of submicron organic aerosols during wintertime inversions by advanced factor analysis of aerosol mass spectra, Environ. Sci. Technol., 42, 214-220, 2008.

Matson, P., Lohse, K. A., and Hall, S. J.: The globalization of nitrogen deposition: Consequences for terrestrial ecosystems, Ambio, 31, 113-119, 2002.

Murphy, B. N., Donahue, N. M., Robinson, A. L., and Pandis, S. N.: A naming convention for atmospheric organic aerosol, Atmos. Chem. Phys., 14, 5825-5839, 2014,

http://www.atmos-chem-phys.net/14/5825/2014/.

Ng, N. L., Canagaratna, M. R., Zhang, Q., Jimenez, J. L., Tian, J., Ulbrich, I. M., Kroll, J. H., Docherty, K. S., Chhabra, P. S., Bahreini, R., Murphy, S. M., Seinfeld, J. H., Hildebrandt, L., Donahue, N. M., DeCarlo, P. F., Lanz, V. A., Prévôt, A. S. H., Dinar, E., Rudich, Y., and Worsnop, D. R.: Organic aerosol components observed in Northern Hemispheric datasets from Aerosol Mass Spectrometry, Atmos. Chem. Phys., 10, 46254641, doi:10.5194/acp-10-4625-2010, 2010.

Ng, N. L., Canagaratna, M. R., Jimenez, J. L., Zhang, Q., Ulbrich, I. M., and Worsnop, D. R.: Real-time methods for estimating organic component mass concentrations from aerosol mass spectrometer data, Environ. Sci. Technol., 45, 910-916, 2011 a.

Ng, N. L., Herndon, S. C., Trimborn, A., Canagaratna, M. R., Croteau, P. L., Onasch, T. B., Sueper, D., Worsnop, D. R., Zhang, Q., Sun, Y. L., and Jayne, J. T.: An aerosol chemical speciation monitor (ACSM) for routine monitoring of the composition and mass concentrations of ambient aerosol, Aerosol Sci. Technol., 45, 770-784, 2011b.

Paatero, P.: The multilinear engine - A table-driven, least squares program for solving multilinear problems, including the n-way parallel factor analysis model, J. Comput. Graph. Stat., 8, 854888, 1999.

Paatero, P. and Hopke, P. K.: Rotational tools for factor analytic models, J. Chemometrics, 23, 91-100, 2009.

Paatero, P. and Tapper, U.: Positive matrix factorization - a nonnegative factor model with optimal utilization of error-estimates of data values, Environmetrics, 5, 111-126, 1994.

Paatero, P., Hopke, P. K., Song, X. H., and Ramadan, Z.: Understanding and controlling rotations in factor analytic models, Chemometr. Intell. Lab., 60, 253-264, 2002.

Peng, R. D., Dominici, F., Pastor-Barriuso, R., Zeger, S. L., and Samet, J. M.: Seasonal analyses of air pollution and mortality in 100 US cities, Am. J. Epidemiol., 161, 585-594, 2005.

Pfaffenberger, L., Barmet, P., Slowik, J. G., Praplan, A. P., Dommen, J., Prévôt, A. S. H., and Baltensperger, U.: The link between organic aerosol mass loading and degree of oxygenation: an $\alpha$ pinene photooxidation study, Atmos. Chem. Phys., 13, 64936506, doi:10.5194/acp-13-6493-2013, 2013.

Seinfeld, J. H. and Pandis, S. N.: Atmospheric Chemistry And Physics, From Air Pollution To Climate Change, 2nd Edn., John Wiley \& Sons, Hoboken, 2006.

Slowik, J. G., Wong, J. P. S., and Abbatt, J. P. D.: Real-time, controlled $\mathrm{OH}$-initiated oxidation of biogenic secondary organic aerosol, Atmos. Chem. Phys., 12, 9775-9790, doi:10.5194/acp12-9775-2012, 2012.

Smiatek, G. and Steinbrecher, R.: Temporal and spatial variation of forest VOC emissions in Germany in the decade 1994-2003, Atmos. Environ., 40, S166-S177, 2006. 
Ulbrich, I. M., Canagaratna, M. R., Zhang, Q., Worsnop, D. R., and Jimenez, J. L.: Interpretation of organic components from Positive Matrix Factorization of aerosol mass spectrometric data, Atmos. Chem. Phys., 9, 2891-2918, doi:10.5194/acp-9-2891-2009, 2009.

Watson, J. G.: Visibility: Science and regulation, J. Air Waste Manage. Assoc., 52, 628-713, 2002.

Weimer, S., Alfarra, M. R., Schreiber, D., Mohr, M., Prévôt, A. S. H., and Baltensperger, U.: Organic aerosol mass spectral signatures from wood-burning emissions: Influence of burning conditions and wood type, J. Geophys. Res.-Atmos., 113, D10304, doi:10.1029/2007JD009309, 2008.
Zhang, Q., Jimenez, J. L., Canagaratna, M. R., Ulbrich, I. M., Ng, N. L., Worsnop, D. R., and Sun, Y.: Understanding atmospheric organic aerosols via factor analysis of aerosol mass spectrometry: a review, Anal. Bioanal. Chem., 401, 3045-3067, 2011.

Zotter, P., Ciobanu, V. G., Zhang, Y. L., El-Haddad, I., Macchia, M., Daellenbach, K. R., Salazar, G. A., Huang, R.-J., Wacker, L., Hueglin, C., Piazzalunga, A., Fermo, P., Schwikowski, M., Baltensperger, U., Szidat, S., and Prévôt, A. S. H.: Radiocarbon analysis of elemental and organic carbon in Switzerland during winter-smog episodes from 2008 to 2012 - Part 1: Source apportionment and spatial variability, Atmos. Chem. Phys., 14, 1355113570, doi:10.5194/acp-14-13551-2014, 2014. 